\title{
Creation and validation of a health guidance booklet for family members of children with sickle cell disease ${ }^{a}$
}

\author{
Elaboração e validação de caderneta de orientação em saúde para familiares de crianças com \\ doença falciforme \\ Elaboración y validación de libreta de orientación en salud para familiares de niños con enfermedad \\ falciforme
}

\author{
Sarah Vieira Figueiredo ${ }^{1}$ \\ Thereza Maria Magalhães Moreira ${ }^{1}$ (it) \\ Clarice Santos Mota $^{2}$ (C) \\ Roselene Soares de Oliveira ${ }^{1}$ (D) \\ Ilvana Lima Verde Gomes ${ }^{1}$ (C)
}

1. Universidade Estadual do Ceará. Fortaleza,

CE, Brasil

2. Universidade Federal da Bahia. Salvador,

BA, Brasil

Corresponding author:

Sarah Vieira Figueiredo.

E-mail:sarahvfigueiredo@gmail.com.

Submitted on $08 / 03 / 2018$.

Accepted on 12/01/2018.

DOI: 10.1590/2177-9465-EAN-2018-0231.

\begin{abstract}
The aim of this study was to elaborate a booklet for health follow-up and guidance on sickle cell disease for relatives of children with this disease and validate it. It is a methodological study, conducted from May 2017 to February 2018, of the elaboration and validation of an educational technology, constructed from previous field research in a pediatric hospital in Ceará (ethical opinion no 994.879 and $n=955.727$ ). Validation of content and appearance occurred by specialized, technical and communication judges; after the adjustments, the evaluation by representatives of the target public took place. The analysis was through the Concordance Index. Results: the evaluation of technical judges and experts reached a Global Concordance Index of 0.93 , characterizing the book as good quality. The judges of communication evaluated all items as Superior. As for family members, everyone agreed that the book was adequate. It is concluded that the booklet has been duly drawn up and validated as regards its content and its appearance. Implications for practice: this educational technology is an important instrument to be used by health professionals, aiming to contribute to increase the knowledge of the relatives of children with sickle cell disease.
\end{abstract}

Keywords: Anemia, Sickle Cell; Educational Technology; Child; Family.

\section{Resumo}

Objetivou-se elaborar uma caderneta de acompanhamento e orientação em saúde sobre a doença falciforme para familiares de crianças com essa enfermidade, e realizar a sua validação. Trata-se de estudo metodológico, realizado de maio de 2017 a fevereiro de 2018, de elaboração e validação de uma tecnologia educacional, construída a partir de pesquisa de campo prévia em hospital pediátrico do Ceará (parecer ético ㄲo1.994.879 e ㄲo1.955.727). A validação de conteúdo e aparência aconteceu por juízes especialistas, técnicos e de comunicação; após os ajustes, ocorreu a avaliação por representantes do público alvo. A análise foi através do Índice de Concordância. Resultados: A avaliação dos juízes técnicos e especialistas alcançou Índice de Concordância global de 0,93 , caracterizando a caderneta como de boa qualidade. Os juízes de comunicação avaliaram todos os itens como superior. Quanto aos familiares, todos concordaram que a caderneta estava adequada. Conclui-se que a caderneta foi devidamente elaborada e validada quanto ao seu conteúdo e a sua aparência. Implicações para a prática: essa tecnologia educacional constitui importante instrumento a ser utilizado por profissionais de saúde, visando contribuir para o aumento do conhecimento dos familiares de crianças com doença falciforme.

Palavras-chave: Anemia Falciforme; Tecnologia Educacional; Criança; Família.

\section{Resumen}

Se pretendió elaborar una libreta de acompañamiento y orientación en salud sobre enfermedad falciforme para familiares de niños enfermos y realizar su validación. Método: Estudio metodológico, realizado de mayo 2017 a febrero 2018, de elaboración y validación de una tecnología educativa, construida a partir de investigación de campo previa en un hospital pediátrico de Ceará (dictamen ético ํㅜ․994.879 y nำ1.955.727). Validación de contenido y forma se produjo por jueces expertos, técnicos y de comunicación; después ocurrió la evaluación por representantes del público-objetivo. Análisis por Índice de Concordancia (IC). Resultados: Evaluación de jueces técnicos y expertos alcanzó IC global 0,93, caracterizando la libreta como de buena calidad. Los de comunicación evaluaron todos los ítems como Superior. Para los familiares, todos la consideraron adecuada. Conclusión: Se evaluó la libreta por su contenido y forma. Implicaciones para la práctica: Esta tecnología educativa es un importante instrumento para profesionales de salud, con el fin de contribuir al aumento del conocimiento de los familiares de niños con enfermedad falciforme.

Palabras clave: Anemia de Células Falciformes; Tecnología Educacional; Niño; Familia. 


\section{INTRODUCTION}

Sickle diseases are a serious public health problem, affecting millions of people around the world, with high mortality and morbidity rates. They are caused by a genetic change that results in the formation of a hemoglobin $(\mathrm{Hb}) \mathrm{S}$, or other mutant hemoglobins, which have different properties of the molecule of hemoglobin A. ${ }^{1-2}$

Thus, the combinations of a mutant $\mathrm{Hb}$ with another of type S constitute sickle diseases, such as: sickle cell anemia (Hb SS), $\mathrm{S}$ beta thalassemia and the double heterozygous $\mathrm{HbSC}$ and $\mathrm{HbSD}$, the most severe being $\mathrm{HbSS}$ and $\mathrm{Hb}$ S beta thalassemia. ${ }^{3}$

Because of this mutation, red blood cells undergo a process of change in their morphological conformation, assuming the shape of a scythe, which affects the adequate blood flow through the vessels. In this way, vasoconstriction occurs, venous stasis and reduction of oxygen supply to the tissues in several organs, which promotes its progressive lesion and painful crises. ${ }^{4}$

As for the child, from the six months of life onwards it is possible to start some diseases, such as: chronic anemia, severe infectious processes, pain crises, as well as complications such as stroke, between others that can compromise multiple organs. ${ }^{5-6}$ In this way, continuous health care is needed from a very early age.

The diagnosis is made in the Unified Health System, through the National Neonatal Screening Program (PNTN), where the blood of the neonate is collected at the heel and is called the "test of the foot". In addition to hemoglobinopathies, other disease can also be diagnosed by this test, making possible early treatment, which should be available in the public health system, in order to reduce complications and provide conditions for the affected population to achieve a better quality of life. ${ }^{5}$

Thus, because of the different clinical peculiarities of sickle-cell disease and the importance of lifelong health follow-up, it is emphasized that the relatives of these children need to be properly oriented about this disease, the necessary care, as well as about the early identification of signs of risk for complications, with a view to preventing its aggravation.

With the news of the diagnosis of sickle cell disease in the child, family members begin to deal with feelings of fear and insecurity, in the face of a process that is often unknown to them, which generates expectations of obtaining more health information about what can happen with their children and what actions they should develop. ${ }^{7}$

When symptoms and treatment begin, the family can better understand the severity of the disease and the need for intensive health care, and the importance of receiving appropriate guidelines for the prevention of complications in the child's body. ${ }^{8}$

However, national and international literature has revealed that many family members and caregivers have had low knowledge about sickle cell disease, its pathophysiology, genetic inheritance, complications, necessary care, among other information. ${ }^{9-12}$

From this perspective, it is pointed out that health education aims to promote self-care in people with sickle cell disease; when infants, this care is linked to the relatives, because these people are dependent on others with greater age and knowledge. In this way, professionals must establish an educational process and preparation for both the sick and their families, related to daily activities, health maintenance, complications prevention and crisis management. ${ }^{13}$

The educational technology comprises a strategy that can be used within the health education process, helping in the mediation of the activities carried out by the facilitators, during the sharing of the information, and, to that end, involve actions that meet the needs of the target audience. technology is intended. ${ }^{14}$

In this sense, it is highlighted that the elaboration of printed technologies (such as a notebook) is intended, among other aspects, to facilitate the assistance provided by health professionals, during the orientation process for users and their families, regarding the illness, treatment, and self-care activities. Therefore, they help to standardize guidelines and help the community to better understand its health-disease process and to consciously seek out the paths to be followed for its recovery. ${ }^{15}$

However, the absence of a printed educational technology for family members of children with sickle cell disease, available in the literature, was observed. In this sense, in view of the importance of creating a strategy to increase the knowledge of these people, this research aimed to elaborate a health monitoring and guidance booklet on sickle cell disease for family members of children with this disease and validate it.

\section{METHOD}

It is a methodological research, of internal elaboration and validation of an educational technology. The methodological research aims at the realization, improvement and evaluation of an instrument or a strategy that makes possible to improve a methodology.$^{16}$ In addition, this type of study seeks to elaborate, validate and evaluate instruments / techniques, aiming at the construction of a reliable instrument, that is possible its later use. $^{17}$

For that, the steps based on the recommendations that have been reference in several researches in the guidance on how to develop manuals of education in health were followed. ${ }^{15}$ However, a "Situational Diagnosis" phase was included, and another was "Selection of content to be addressed in the Booklet". In summary, the steps were: 1) Approval of the project in the Research Ethics Committee; 2) Situational Diagnosis; 3) Review of literature and documentary; 4) Selection of Content; 5) Preparation of the Booklet; 6) Internal validation.

\section{From situational diagnosis to carnet elaboration}

After approval of the project (described below), we sought to hear relatives of children with sickle cell disease in a pediatric referral service in Ceará, located in Fortaleza, in the waiting room of the specialty clinic, through individual semi-structured interviews, focusing on questions that sought to understand the main orientation needs of these people (situational diagnostic phase).

Subsequently, a literature and documentary review on the 
themes to be addressed in the booklet was carried out, through searches in some databases, in May 2017, as LILACS (Latin American and Caribbean Literature in Sciences of the Health), MEDLINE (Medical Literature Analysis and Retrieval System Online)/ Pubmed, SCIELO (Scientific Eletronic Library Online) and BDENF (Database of Nursing), using the words: "anemia, sickle cell", "health education", "sickle cell disease" and "education", associated.

Also in this phase, a review of the documents in force in Brazil dealing with sickle-cell diseases and the rights guaranteed to people with this disease was carried out; a review was also carried out on books, manuals and booklets of the Ministry of Health that deal with aspects inherent to this disease. Thus, this information provided a theoretical and scientific basis for the content addressed in the Booklet.

After this review, together with the findings found in the situational diagnostic phase, the contents were selected, being prepared in a way that there were groupings of subjects that were related, seeking to facilitate the readers' understanding of the subject, in order to be created chapters for the presentation of printed educational technology.

The booklet was divided in two parts, the first of general health guidelines on sickle cell disease and the second with spaces for health professionals' records, communication between health services and family notes. In each part, chapters were defined, and, from these, the illustrations were created in order to facilitate the understanding of the target public, through pictures and figures. ${ }^{15}$ At that moment, there was the participation of a graphic design professional for its elaboration.

The scientific language was made easy for the target public to understand, with the technical and scientific terms being difficult to understand, or when it was not possible to remove them, a simpler definition was included.

\section{Internal validation}

Regarding the validation process, authors talk about the need for the elaborated printed educational technologies to be submitted to the analysis of people with great knowledge and experience in the area (judges), as well as those who will be the target audience for the technology. ${ }^{14}$ Validation, therefore, is a way of thoroughly examining an instrument produced, so that it can be verified whether it measures exactly what it proposes.

For a better evaluation process, it is suggested that it be carried out by professionals from different areas of knowledge. ${ }^{15}$ In this sense, from a "snowball" type sampling (called network sampling), which began with the search of participants in the Platform of the National Council for Scientific and Technological Development (CNPq), through the subject "sickle cell disease", nine technical judges (doctors or masters with a high degree of knowledge about the contents of the book), eight technical judges (professionals and health workers with medical or health care experience in sickle cell disease) and seven judges of communication (professionals with experience in social communication and/or graphic design). ${ }^{16,18}$
At that moment, there was no restriction on the location of these professionals, and, in the end, there were people from different Brazilian regions, which contributed to the validation process, through various experiences on sickle cell disease among the cities, were: Mato Grosso, Minas Gerais, Bahia, Mato Grosso do Sul, Rio de Janeiro, São Paulo and Ceará. A Brazilian judge residing in the United States, who has developed studies on sickle cell disease in that country, also participated.

This phase of validation of content and appearance took place from August to October 2017, and invitations were sent electronically or in person. After accepting and signing the Free and Informed Consent Form (ICF), the booklet was sent together with the evaluation instrument. The initial deadline for the return was 15 days, being extended by another 15 to 30 days, depending on the request of the judge.

The expert and technical judges used the same instrument, composed of two evaluation parts: the first contained items related to the analysis of the objectives, structure, presentation and relevance of the book, adapted from Oliveira ${ }^{19}$ (for each question, the judge could mark: 1-unsuitable, 2-partially adequate, 3-suitable and 4-fully adequate); the calculation of the score was made from the amount of items that received a score between 3 and 4 , being the ones with the lowest score eliminated or reviewed by the researchers. Thus, the Concordance Index $(\mathrm{Cl})=$ number of responses with values of 3 and 4/total number of responses.

The second part of the instrument was composed of items that assessed all subjects in a more detailed way, being adapted from Barbosa, where, for each topic covered, the judges answered "yes" or "no" as to clarity, comprehension and relevance, and, lastly, the degree of suitability (1-inadequate, 2-partially adequate, 3-adequate, 4-fully adequate). ${ }^{20}$

After the evaluation, the $\mathrm{Cl}$ was applied to assess the proportion of judges in agreement on the aspects contained in the instrument, related to content and appearance; the items with concordance $>$ or $=0.78$ were considered adequate..$^{21-22}$ To quantify the level of agreement in relation to the second part of the instrument, those that reached an index equal to or greater than $80 \%$ were considered valid. ${ }^{20}$

On the other hand, the judges of communication used an instrument adapted from Doak, Doak and Root ${ }^{23}$, Suitability Assessment of Materials - SAM, evaluating the suitability of the book based on the aspects related more specifically to this professional category, such as: layout and presentation, language, graphic illustrations, motivation and cultural adequacy. According to this instrument, each evaluated item receives a score, being " 0 " (inadequate), "1" (partially adequate) or "2" (adequate).

Thus, following the recommendations of these authors, the sum of all the points of the communication professionals was divided by the maximum possible total score and then multiplied the result by 100 , obtaining, in this way, a percentage. If this percentage was between $70-100 \%$, it would mean that the material was very suitable; and more than or equal to $40 \%$ would be considered adequate..$^{23}$

After these analyzes, the necessary changes were made, 
according to the final score, regarding items with low scores. In addition, the observations and suggestions of the judges were also appreciated as to the need for material changes.

Following the validation of content and appearance, the analysis of the organization, appearance, motivation and learning was performed with 12 family members representing the target audience to which the book was destined, selected through non-probabilistic sampling by criteria of convenience. It was developed at the pediatric referral hospital in Ceará, mentioned above, in the waiting room of the specialty clinic in December 2017. For that, an evaluation instrument was used with four topics related to the aspects under analysis. It was considered that the book would be adequate, when a percentage of positive responses ("yes") greater than or equal to $70 \%$ was reached; and items with negative evaluation and/or suggestions were used to reorganize the final version of the Booklet.

\section{Ethical aspects}

It should be noted that all the recommendations of the National Health Council were followed through Resolution 466/2012. The research was approved by the Research Ethics Committee of the State University of Ceará (opinion 1.955.727) and the hospital scenario of data collection (No. 1,994,879). All participants signed the ICF, being guided about the risks and benefits of the research, the possibility of being able to give up their participation at any time and that they would not have any burden.

\section{RESULTS}

After the elaboration, the booklet contained 63 pages, and from page 10 to 41 the contents of orientation to the relatives were described; from pages 42 to 60 , the spaces related to the child's health records were inserted.

The topics selected from the demands of the relatives of children with sickle cell disease, together with the findings found in the literature review (totaling only six articles on health education activities about sickle cell disease after the searches presented in the methods) were: information on human blood, definition of sickle cell disease and sickle cell trait, genetic inheritance in sickle cell disease, signs and symptoms, major complications and necessary care, health diagnosis and follow-up, treatment, bone marrow transplantation, with food, health rights and how to deal with the disease in the child's life.

As regards the records: the child's appointment schedule, daily medications, laboratory tests, other examinations of the child, vaccination records, health professionals' notes, observations on the child's health (in seizures and blood transfusions), hospitalizations, space for communication between health services and family notes.

\section{Characterization of study participants}

As to the profile of the nine specialist judges, there was a predominance of female subjects $(77 \%)$. In relation to age, $66.6 \%$ were older than 50 years. The majority $(77.6 \%)$ had more than 20 years of professional training, revealing judges with a greater degree of experience in their work area.

Among the basic formations, it was possible to obtain the participation of professionals from different areas of knowledge, in order to also contribute to the evaluation process, from different visions; such as: psychology, nursing, nutrition, medicine, biology and anthropology. Of these professionals, the predominance of nursing (44\%).

Regarding the area of work, only one of the judges did not practice teaching activities. As for titration, three were masters, five were doctors, and one was a postdoctor. All participated in research projects on sickle cell disease and six judges had theses or dissertations on this subject. Everyone had articles and / or book chapters focusing on this disease. Thus, these aspects reaffirmed the degree of knowledge of these professionals about the area under study, as well as their wide experience in the contents presented in the book.

Of the eight technical judges, women (75\%) also predominated. As for the age group, $50 \%$ were between 40 and 49 years of age. Four were doctors, one was a dentist, two were nurses, and one was a pharmacist; $75 \%$ of these professionals had more than 20 years of training. In this sense, we can also see that this group of professional judges had extensive professional experience.

In relation to the degrees, five were specialists, one was master and two were doctors; four had developed papers on the subject in the postgraduate course. Almost all were involved in groups or research on sickle cell disease ( $87.5 \%)$; all had participated in events and presented papers on this subject; $63 \%$ had professional experiences directly related to the care of people with sickle cell disease, and the others had health education activities about the disease.

Regarding communication judges, $57.1 \%$ were women. As for the age group, $42.9 \%$ were between 20 and 29 years old and $42.9 \%$ between 30 and 39 years old. Regarding academic training, $42.9 \%$ were Graphic Designs, $42.9 \%$ Advertising and only one participant was Marketing Analyst. The training time ranged from two to 28 years, with $57.1 \%$ having up to five years of training. The majority $(71.4 \%)$ had already produced manuals, books, booklets or other widely disseminated social documents; $85.7 \%$ had experience in Art Direction; and $85.7 \%$ had already done work in the area of health or education.

As for the 12 representatives of the target public, all were mothers of children with sickle cell disease and $50 \%$ were between 18 and 24 years of age. In relation to schooling, 58.33\% had completed High School and $41.67 \%$ were Incomplete or Complete Elementary School, revealing a profile of participants with different levels, which contributed to a better process of assessing the booklet, from people with degrees of knowledge.

As for marital status, the majority were married or lived in a stable union (66.7\%). Only one participant had formal employment, as a teacher, and the others had activities in their homes and care of their children $(91.7 \%)$.

\section{Content and appearance validation}

As regards the evaluation carried out by the group of tech- 
nical judges and experts, who have used the same instrument to validate the book on content and appearance, the following Table 1 presents the results of the first part of this instrument, with respect to the items: objectives, structure, presentation and relevance, as well as the IC achieved in each subitem evaluated.

As can be seen in the table below, all items obtained $\mathrm{Cl}$ greater than 0.78 , minimum value that should be punctuated to validate the book as a good quality material. The lowest score was $\mathrm{Cl}=0.82$ and the maximum $\mathrm{Cl}=1$. The overall average of the book, which was the sum of all the points reached, divided by the maximum score that could have been reached, was 0.93 , revealing an educational technology with good quality and rigorously validated in content and appearance, by those professionals with high knowledge on the subject.

Table 1. Evaluation of technical judges and experts - Instrument I. Fortaleza -CE, Brazil, 2017.

\begin{tabular}{llr}
\hline Items & $\mathrm{N}$ & Score \\
\hline $\begin{array}{l}\text { Objectives } \\
\text { 1.1 Are consistent with the guidance needs of people with } \\
\text { sickle cell disease and their family members }\end{array}$ & 17 & 1 \\
$\begin{array}{l}1.2 \text { Promotes behavior change and attitude } \\
1.3 \text { It may circulate in the scientific field in the area of sick- }\end{array}$ & 17 & 1 \\
le cell disease & 14 & 0.82
\end{tabular}

\section{Structure and Presentation}

2.1 The Handbook is appropriate for people with sickle cell disease and their family members

2.2 The messages are presented in a clear and objective way

2.4 The material is appropriate to the socio-cultural level of the proposed target audience

2.5 There is a logical sequence of proposed content

2.6 The information is well structured in agreement and spelling

2.7 Cover, back cover, summary and presentation information are consistent

2.8 The illustrations are expressive and enough

\section{Relevance}

3.1 Topics cover key aspects that need to be strengthened

3.2 The material proposes to the reader to acquire knowledge about sickle cell disease

3.3 The material addresses subjects necessary for the prevention of complications in sickle cell disease and guidelines for appropriate decision-making in the face of crises 
Regarding the second part of the assessment instrument, carried out by the subjects of the booklet, everyone obtained a high level of agreement among the judges as to the clarity, comprehension and importance of the subjects being dealt with in the book (ranging from $88.24 \%$ to $100 \%$ ). Regarding the degree of appropriateness of the topics, nine had a $\mathrm{Cl}$ between $82 \%$ and $100 \%$, and only two subjects presented low scores $(\mathrm{Cl}=65 \%$ in subjects related to the general explanation about sickle cell disease and $\mathrm{Cl}=76 \%$ in subjects related to treatment).

Among the main recommendations provided by these judges, the following stand out in Chart 1:
All the suggestions presented in Chart 1 were accepted by the researchers, based on the relevant scientific literature, especially those related to the topics with lower Cls, in order to make them more appropriate. However, some observations have not been adhered to, as they are contrary to national and international evidence, do not bring greater benefits to the book and/or represent occasional opinions/suggestions.

Regarding the evaluation developed by the communication judges, all classified the booklet as Superior (scores above 20 and percentage higher than 70 ), revealing the adequacy of the educational technology elaborated, as shown in the Table 2.

Chart 1. Suggestions from technical judges and experts based on the chapters of the booklet. Fortaleza -CE, Brazil, 2017.

\begin{tabular}{l}
$\begin{array}{l}\text { Chapters of the } \\
\text { Booklet }\end{array}$ \\
\hline
\end{tabular}

General Suggestions

- Revision of Portuguese and grammatical; Review paragraph formatting;

- Add chapter with guidelines on the school;

- Keep only the term hereditary or genetic in the phrase "it is a genetic and hereditary disease", because they are synonymous;

And what, after all, is sickle cell disease?

\section{How Can One Get Sickle Cell Disease

How Can One
Get Sickle Cell
Disease

What complications can happen?

\section{How is the tre- atment?}

Caring for food

Child Health Records
- Replace "erythrocytes other than normal" by a text that includes the types of hemoglobin present, so as not to stigmatize the phrase;

- Include in the texts hemoglobin A and S or another mutant, to facilitate explanation, especially in the context of sickle cell trait;

- Include the situations that lead the red blood cells to take the form of sickle;

- Replace "from parents to children" with "an illness that children inherit from their parents" because the first version is criticized by people with sickle cell disease;

- Redo image.

- Change the title of the chapter by "How can one be born with sickle cell disease";

- Improve the description of the sickle cell trait. Include explanation about mutant genes.

- Remove the word "carrier" from the subtitles.

- Improve the image of the girl with symptoms of stroke. Include text that talks about the importance of transcranial Doppler in preventing stroke. Replace the word "infarction" with a clearer one with brain injury;

- Improve the text that talks about complications in the spleen, to facilitate the understanding. Include an image that explains the correct way to palpate this organ. Replace the word "worse" with "more serious".

- Add the effects of hydroxyurea;

- Include transcranial Doppler examination;

- Improve the text, with the help of nutritionists working on sickle cell disease;

- Reorganize text related to iron and vitamin C, to facilitate understanding;

- Reformulate table with exams;

- Add observations from the school;

- Include registration chart for Iron chelation scheme and adverse events;

Source: Elaborated by the authors. 
Table 2. SAM score of the communication judges. Fortaleza-CE, Brazil, 2017.

\begin{tabular}{|c|c|c|c|}
\hline & $\begin{array}{l}\text { SAM } \\
\text { Score }\end{array}$ & Percentage & Classification \\
\hline Judge 1 & 27 & $96 \%$ & Superior \\
\hline Judge 2 & 27 & $96 \%$ & Superior \\
\hline Judge 3 & 27 & $96 \%$ & Superior \\
\hline Judge 4 & 21 & $78 \%$ & Superior \\
\hline Judge 5 & 21 & $78 \%$ & Superior \\
\hline Judge 6 & 26 & $93 \%$ & Superior \\
\hline Judge 7 & 26 & $93 \%$ & Superior \\
\hline
\end{tabular}

Source: Elaborated by the authors.

Minor remarks have been made by some, including suggestions for improving the book, such as: leave the title on the cover with words at the same time; change the children's place on the cover and approach the characters so that they seem to be a family; improve text formatting, aligning left in "justified" mode; redo the summary in order to favor the reading, without the icons in the form of red cells, putting them as an illustration and not as page identification; among others.

Thus, the contributions of these professionals were followed in order to improve the book and, after the necessary adjustments, it was evaluated by the representatives of the target public. All of them $(100 \%)$ agreed that the book was properly organized, through a cover that attracted the attention of the readers, a content properly sequenced and through an organization that facilitated the reading and understanding of the contents.

For all participants the language was also adequate, with easy-to-understand phrases, use of simple words and explanations for the difficult ones. They also stated that they were able to understand all the information in the book.

As for appearance, everyone agreed that the illustrations facilitated the understanding of the text, were interesting and were easy to understand. In relation to motivation and learning, everyone stated that the contents of the book were interesting and motivated reading; in addition, all stated that they had learned new information and that they were encouraged to think more about the child's health and the necessary care.

Concerning the suggestions, only one participant requested that further information on the type of sickle cell disease HbSS was described, since, according to her, it was the most important type because of its severity. However, it was not possible to expand information on this specific type of disease, since the booklet aims to provide general information on all sickle cell diseases without specific approaches.

All the mothers brought positive remarks about the book, as you say:
I found it very important, because I had already searched in other books, but it was not easy to understand, and in that book simplified, the figurines helped and understanding as well. (PA1)

[...] I had a lot of doubts too, only the little I read already gave to clear the doubts, I think it was good for the mothers to receive to clear the doubts (PA5).

Thus, the family members reaffirmed the importance of this educational technology in the orientation process, both for them and for other relatives. Thus, the carnet was duly evaluated by the target public, and the internal validation process was concluded.

\section{DISCUSSION}

The literature has revealed the importance of educational technologies that are built based not only on the researchers' opinion and experience. Thus, during the selection of the content to be approached in these materials, it becomes essential to seek to understand the target audience for which it is intended and its real needs. ${ }^{24-25}$ Therefore, a situational diagnosis, as was done in the present study, tends to contribute to the quality of the chosen content.

Regarding the process of validation by professionals and workers from different areas of knowledge, it was observed that it was of great relevance for the improvement of the book, since it was possible to obtain opinions and different views on the contents addressed, which would probably have been incipient with the restricted participation of a professional group.

Other research has reinforced the importance of this expansion in the diversity of professional judges as a contributing factor to the formation of a more complete educational technology. ${ }^{26-27}$ For a better evaluation process, it is suggested that it be performed by professionals from different areas of knowledge, such as educators, health professionals and social communicators, so that the validation is done in a team, valuing different perceptions about the same subject matter. ${ }^{15}$

In the process of validation by technical judges and specialists, the objectives (related to the orientation needs of people with sickle cell disease and their relatives), the structure and presentation of the book (involving the adequacy of writing, logical sequence, spelling, illustrations, among others aspects), as well as their relevance to the topics covered, obtained $\mathrm{Cl}$ between 0.82 and 1 , which revealed a concordance among the judges regarding the quality of the book.

The concordance rates considered acceptable are variable and the literature recommends that they be between $70-100 \%$, and that in this research was used a value greater than or equal to $0.78(\mathrm{Cl}>0.78)$, since it is estimated as a value which reveals good property of the material elaborated..$^{14,22}$ 
The subitems that achieved lower $\mathrm{Cl}$ scores (0.82) were: "may circulate in the scientific milieu in sickle cell disease"; "The information presented is scientifically correct", "the material is appropriate to the socio-cultural level of the proposed target audience", and "the information is well structured in agreement and spelling." In this way, the judges' recommendations were followed, and the content was revised as regards the scientific basis, the cultural context of the target audience and revised grammatically.

The reformulation of the book was also carried out based on the second part of the validation process of the expert and technical judges, where two topics presented low scores, as previously described. In general, the main contributions, as described in Chart 1, were related to the substitution and addition of some terms, modification of some illustrations and withdrawal of stigmatizing words or phrases, in order to facilitate the understanding of the target public regarding the guidelines presented. The requests submitted were accepted, including the insertion of a chapter on the guidelines on the school, the addition of a page to record information in this environment and another on the scheme of chelation of iron and adverse events.

Despite the various suggestions, it should be noted that the overall mean of the booklet was high (0.93). In this sense, other researches have also found similar results, where although the educational materials were well evaluated by the judges, they made contributions and observations in order to improve the quality of the material for the target audience. ${ }^{27-28}$

As for the evaluation made by the judges of communication, it can prove the pertinence of the organization, layout, illustrations and other graphical compositions of the book, as well as the adequacy of the written text, according to the vision of professionals who act directly with these visual concepts. Other research has also emphasized the importance of their participation in the process of validating educational technologies. ${ }^{29-31}$

After the contributions of this group of professionals were implemented, the booklet was printed and delivered to the families of children with sickle cell disease, to complete the evaluation process.

This analysis is seen as a subjective way of validating an educational technology, however it includes the evaluation of important points such as: clarity, readability, form of presentation and understanding of the instrument. At this stage, there should be participation of representatives of the target audience, that is, people with a convergent profile for the technology developed. ${ }^{14}$

Through this evaluation, it was observed that all the family members agreed with the quality of the book, which was confirmed by their reports, where it was noticed that all emphasized that the educational technology clarified many doubts that they possessed, to present a language simpler, along with adequate and clear illustrations, which contributed to a better understanding of the information about sickle cell disease. It was also highlighted the importance of this material to other relatives, as it would be very useful to help other people who have had little access to guidelines on this disease.
In its recommendations on the development of educational manuals, the author stresses that it is essential to transform the scientific language described in the literature into an easy-to-understand reader, insofar as these tools must be created in order to strengthen the guidelines to the patients and their families, being necessary the existence of a language that attends to the different levels of schooling of the population. ${ }^{27}$

Differing from our findings, another validation study with adolescents found an agreement of $88.4 \%$ among the participants, representing the target audience, to the extent that many people reported not feeling at ease, or only in part, to read the elaborate primer. ${ }^{27}$

On the other hand, a validation research of an educational booklet for healthy eating during pregnancy, showed that the material elaborated was considered adequate by the participating women, however, the authors pointed out that the low level of schooling seemed to have contributed to the smallest number of suggestions. ${ }^{32}$

In the study developed by Rocha, Cioff and Oliveira ${ }^{4}$, these authors observed that one of the strategies that can be used in the search to increase the knowledge of family members/caregivers of children with sickle cell disease is the use of written materials that are culturally adapted and sensitive to the target audience of the educational process through of simple language and easy understanding to these people.

Thus, the present research was able to reach this goal, inasmuch as the book was well received by family members, who emphasized their contributions to increase their knowledge about this disease and the necessary care for the child.

\section{FINAL CONSIDERATIONS AND IMPLICATIONS FOR PRACTICE}

It has been revealed the importance of relatives of children with sickle cell disease to be advised about this disease and its repercussions of the infant's body, which will require lifelong care and constant health monitoring, aiming at avoiding complications and even early deaths.

Faced with this demand, a health guidelines booklet was elaborated, based on the needs evidenced by the family members, along with the discussions in the literature. This educational technology also contains spaces for various health records, such as exam results, professional guidelines, observations during hospitalizations, pain crises, among other aspects, allowing the maintenance of this information along the therapeutic itineraries traced by the child.

In order to guarantee the quality of the book, it has undergone a validation process regarding its content and its appearance, through a thorough multi-professional evaluation, through masters and experts in the subject (expert judges), and professionals who work in the assistance people with sickle cell disease or health education (technical judges), where it reached a global $\mathrm{Cl}$ of 0.93 , revealing the quality of the material; and also by means of the evaluation by workers in the media area (communication 
judges), where everyone classified the passbook as Superior (score higher than $70 \%$ in the SAM score).

After this validation, the book was reorganized based on the judges' suggestions, in order to make it more scientifically adequate, as well as clearer and easier for readers to understand. Later, it was evaluated by family members of children with sickle cell disease, where all agreed that the organization, language, appearance, motivation and learning were adequate, in addition to highlighting the importance of the material to clarify their doubts and other relatives, simple and illustrations that help the understanding about the content covered.

Therefore, it is suggested that this booklet be implemented in the practice of health professionals of different levels of care, functioning as an important tool to support their health education activities, contributing to the care of children with sickle cell disease and strengthening understanding of the family about this process of illness, who may make use of it at home, whenever they feel the need to remember and clarify information.

However, the present study presented limitations, since it was not possible to prepare the book for other sickle-sick people, such as adolescents, adults and pregnant women. Thus, there is a need to develop new studies aimed at meeting the specific needs of these people, in other phases of life, in addition to children. On the other hand, the results discussed in this manuscript could foster the development of new researches and health education strategies, functioning as a basis to start new work on the subject.

\section{REFERENCES}

1. Ramos JT, Amorim FS, Pedroso FKF, Nunes ACC, Rios MA. Mortalidade por doença falciforme em estado do nordeste brasileiro. Rev Enferm Cent O Min [Internet]. 2015 May/Aug;5(2):1604-12. Available from: http:// www.seer.ufsj.edu.br/index.php/recom/article/view/859

2. Fernandes Q. Therapeutic strategies in Sickle Cell Anemia: The past present and future. Life Sci [Internet]. 2017 Jun;178:100-8. Available from: https://www.ncbi.nlm.nih.gov/pubmed/28435037

3. Fields ME Hoyt-Drazen C, Abel R, Rodeghier MJ, Yarboi JM, Compas $\mathrm{BE}$, et al. A Pilot Study of Parent Education Intervention Improves Early Childhood Development among Toddlers with Sickle Cell Disease. Pediatr Blood Cancer [Internet]. 2016 Dec;63(12):2131-8. Available from: https://www.ncbi.nlm.nih.gov/pubmed/27509845

4. Rocha LPO, Cioff ACS, Oliveira DP. Assistência de enfermagem frente à problemática clínica de pacientes portadores de anemia falciforme. Rev Eletrônica UNIVAR [Internet]. 2014;12(2):44-8. Available from:https:// docplayer.com.br/28655755-Interdisciplinar-revista-eletronica-daunivar-issn-x-ano-de-publicacao-2014-n-12-vol-2-pags.html

5. Mota C, Trad LAB, Queiroz MCA, Dias AL. Os desafios do cuidado integral à doença falciforme sob os diversos olhares: o olhar da gestão, o olhar das famílias e usuários e o olhar do serviço e seus profissionais. In: Castellanos M, Trad L, Jorge MSB, Leitão IMTA, orgs. Cronicidade: experiência de adoecimento e cuidado sob a ótica das ciências sociais. Fortaleza (CE): EdUECE;2015. p. 392-425.

6. Usman MRM, Pawara SM, PatilTP. Sickle Cell Disease:An Overview. Journal of Pharmacy Research [Internet]. 2017;11(6):780-6. Available from: http:// jprsolutions.info/article_detail.php?article_id=1772

7. Lebensburger JD, Grosse SD, Altice JL, Thierry JM, Ivankova NV. Understanding and improving health education among first-time parents of infants with sickle cell anemia in Alabama: a mixed methods approach. J Pediatr Hematol Oncol [Internet]. 2015 Jan;37(1):35-42. Available from: https://www.ncbi.nlm.nih.gov/pubmed/25072367
8. GesteiraECR, Bousso RS, Rodarte AC. Uma reflexão sobre o manejo familiar da criança com doença falciforme. Rev Enferm Cent O Min [Internet]. 2016 Sep/Dec;6(3):2454-62. Available from: http://www.seer.ufsj.edu.br/index. php/recom/article/view/758

9. Day LL, Murray E, Treadwell MJ, Lubin BH. Teaching About Genetics and Sickle Cell Disease in Fifth Grade. J Natl Med Assoc [Internet] 2015 Feb;107(1):4-10. Available from: https://www.ncbi.nlm.nih.gov/ pubmed/27282522

10. Shahine R, Badr LK, Karam D, Abboud M. Educational intervention to improve the health outcomes of children with sickle cell disease. J Pediatr Health Care [Internet]. $2015 \mathrm{Jan} / \mathrm{Feb} ; 29(1): 54-60$. Available from: https://www.ncbi.nlm. nih.gov/pubmed/25115311

11. Santos LRO, Rocha SS, Costas RS, Araújo OD, Gouvéia MTO, Araújo AKL Contribuições da enfermagem para os cuidados da criança com doença falciforme. In:Brito MA, Rocha SS, orgs. Enfermeiros que cuidam de crianças. Teresina: EDUFPI; 2015. p. 97-110.

12. Creary S, Adan I, StanekJ, O'Brien SH, Chisolm DJ, Jeffries T, et al. Sickle cell trait knowledge and health literacy in caregivers who receive in-person sickle cell trait education. Mol Genet Genomic Med [Internet].2017 Nov;5(6):692-9. Available from: https://www.ncbi.nlm.nih.gov/pubmed/29178654

13. Santana CA, Cordeiro RC, Ferreira SL. Conhecimento de enfermeiras sobre educação para o autocuidado na anemia falciforme. Rev Baiana Enferm [Internet]. 2013 Jan/Apr;27(1):4-12. Available from: https://portalseer.ufba. br/index.php/enfermagem/article/view/6742

14. Teixeira E, Medeiros HP, Nascimento MHM. Referenciais metodológicos para validação de tecnologias cuidativo-educacionais. In: Nietsche EA, TeixeiraE, Medeiros HP, orgs. Tecnologias cuidativo-educacionais: uma possibilidade para o empoderamento do(a) enfermeiro(a). Porto Alegre: Moriá; 2014. p. 113-27.

15. Echer IC.Elaboração de manuais de orientação para o cuidado em saúde. Rev Latino Am Enferm [Internet]. 2005;13(5):754-7. Available from: www. scielo.br/scielo. php?pid=S0104-11692005000500022\&script=sci_ abstract\&tlng=pt

16. Polit DF, Beck CT. Fundamentos de pesquisa em enfermagem: avaliação de evidências para a prática de enfermagem. Porto Alegre: Artmed 2011.

17. Lobiondo-Wood G, Haber J. Pesquisa em Enfermagem: Métodos, avaliação crítica e utilização. Rio de Janeiro: Guanabara-Koogan;2001.

18. Lopes MV, Silva VM, Araújo TL. Methods for establishing the accuracy of clinical indicators in predicting nursing diagnoses. Int J Nurs Know [Internet]. 2012 Oct;23(3):134-9. Available from: https://www.ncbi.nlm. nih.gov/pubmed/23043652

19. Oliveira MS, Fernandes AFC, Sawada NO. Manual educativo para o autocuidado da mulher mastectomizada: um estudo de validação. Texto Contexto Enferm [Internet]. 2008;17(1):11523. Available from: http://www.scielo.br/scielo. $p h p ?$ pid=S0104 07072008000100013\&script=sci_abstract\&tIng =pt

20. Barbosa EMG, Sousa AAS, Vasconcelos MGF, Carvalho REFL, Oriá MOB, Rodrigues DP. Tecnologias educativas para promoção do (auto) cuidado de mulheres no pós-parto. Rev Bras Enferm [Internet]. 2016;69(3):545-53. Available from: http://www.scielo.br/pdf/reben/ v69n3/0034-7167-reben-69-03-0582.pdf

21. Waltz CW, Bausell RB. Nursing research: design, statistics and computer analysis. Philadelphia (PA): Davis; 1981.

22. Alexandre NMC, Coluci MZO. Validade de conteúdo nos processos de construção e adaptação de instrumentos de medidas. Ciênc Saúde Coletiva [Internet]. 2011;16(7):3061-8. Available from: http://www. scielo.br/scielo.php?pid=S1413-81232011000800006\&script=sci abstract\&tlng=pt

23. Doak CC, Doak GL, Root JH. Teaching patients with low literacy skill. Philadelphia (PA): Lippincott; 1996.

24. Freitas FV, Rezende Filho LA. Communication models and use of printed materials in healthcare education: a bibliographic survey. Interface (Botucatu). [Internet]. 2011 Jan/Mar;15(36):243-55. Available from: http://www.scielo.br/scielo.php?script=sci_arttext\&pid $=$ S1414-32832011000100019 
25. Teles LMR, Oliveira AS, Campos FC, Lima TM, Costa CC, Gomes LFS, et al. Construção e validação de manual educativo para acompanhantes durante o trabalho de parto e parto. Rev Esc Enferm USP. [Internet] 2014;48(6):977-84. Available from:http://www.scielo.br/pdf/reeusp/v48n6/ pt_0080-6234-reeusp-48-06-0977.pdf

26. Cruz FOAM, Ferreira EB, Vasques $\mathrm{Cl}$, Mata LRF, Reis PED. Validação de manual educativo para pacientes com câncer de cabeça e pescoço submetidos à radioterapia. Rev Latino Am Enferm [Internet]. 2016; [cited 2018 Aug 2]; 24:e2706. Available from: http://www.scielo.br/pdf/rlae/v24/ pt_0104-1169-rlae-24-02706.pdf

27. Moura IH, Silva AFR, Rocha AESH, Lima LHO, Moreira TMM, Silva ARV. Construção e validação de material educativo para prevenção de síndrome metabólica em adolescentes. Rev Latino Am Enferm [Internet]. 2017 Oct; [cited 2018 Aug 2]; 25:e2934. Available from: http://www.scielo.br/scielo. php?script=sci_arttext\&pid=S0104-11692017000100383\&Ing=pt

28. Lima ACMACC, Bezerra KC, Sousa DMN, Rocha JF, Oriá MOB. Construção e Validação de cartilha para prevenção da transmissão vertical do HIV. Acta Paul Enferm [Internet] 2017;30(2):181-9. Available from: http:// www.scielo.br/pdf/ape/v30n2/1982-0194-ape-30-02-0181.pdf
29. Galdino YLS. Construção e validação de cartilha educativa para o autocuidado com os pés de pessoas com diabetes [dissertação] Fortaleza (CE): Mestrado em Cuidados Clínicos, Universidade Estadual do Ceará; 2014. Available from: http://www.uece.br/cmacclis/ dmdocuments/YARALANNE.pdf

30. Moura DJM, Moura NS, Menezes LCG, Barros AA, Guedes MVC Construção de cartilha sobre insulinoterapia para crianças com diabetes mellitus tipo 1. Rev Bras Enferm [Internet]. 2017;70(1):3-10. Available from: http://www.scielo.br/pdf/reben/v70n1/en_0034-7167reben-70-01-0007.pdf

31. Santiago JCS. Criação e validação de uma cartilha educativa sobre excesso ponderal para o adulto com hipertensão [tese]. Fortaleza (CE): Universidade Estadual do Ceará; 2016. Available from: http:// www.uece.br/cmacclis/dmdocuments/jenifa.pdf

32. Oliveira SC, Lopes MVO, Fernandes AFC. Construção e validação de cartilha educativa para alimentação saudável durante a gravidez. Rev Latino Am Enferm [Internet].2014 Jul/Aug;22(4):611-20. Available from: http://www.scielo.br/pdf/rlae/v22n4/pt_0104-1169-rlae-22-04-00611. pdf

a Research extracted from the Thesis "Creation and validation of a health guidance booklet for family members of children with sickle cell disease", defended in 2018 in the Postgraduation Program in Collective Health of the State University of Ceará (UECE). 